\title{
Functionalist Regional Cooperation: South Asian Association for Regional Cooperation for Peace in the Region
}

\author{
Nayani Melegoda ${ }^{1}$ and Chaminda Padmakumara ${ }^{2}$ \\ ${ }^{1}$ Dean, Faculty of Graduate Studies, University of Colombo \\ ${ }^{2}$ Department of International Relations, Faculty of Arts, University of \\ Colombo
}

\begin{abstract}
South Asian Association for Regional Cooperation (SAARC) is one of the prominent regional organizations in the world in many aspects such as the largest population and the biggest workforce. Since its inception in 1985, SAARC follows the principles of making decisions by consensus; and non-discussion on contentious bilateral issues. According to the SAARC Charter member states are 'desirous of peace, stability, amity and progress in the region through strict adherence to the principles of the United Nations Charter and Non-Alignment (Ahmed and Bhatnagar, 2008). Somehow, one of the greatest barriers for the SAARC has been recurring inter-state conflicts between member states, which have posed significant challenges (ibid).They are the dilemmas such as overlapping goals and conflicts among its members that make regional cooperation a challenge. The SAARC countries at present experience various security challenges. Peace and Security for the region is one goal that all members would want to achieve amidst insecurity, terrorism and environmental challenges in this century. However, what the 18th SAARC Summit evidently shows is the desire of SAARC to achieve deep cooperation through functional areas.
\end{abstract}


Although vast literature on regional integration has been established, most of them are Eurocentric. Therefore it is worthwhile to examine how such theories can be discussed from the non-European perspectives. In this context, Functionalism has great relevance to understand regional settings out of the Europe. Functionalism as a theory supports the idea of growing interconnectedness and interdependence between nation states located in a specific region (Singh, 2017). David Mitrany, the pioneer of Functionalism specifically mentioned world peace can be achieved through efficient administration of limited resources and use of experts than politicians. More importantly, the core assumption of functionalist theory in this sense is that, as nation's states gets interdependent and interrelated to each other the possibility of bilateral or even regional conflict between nation states gets reduced or even eliminated to a large extent.

With the growing geostrategic, geo political importance of the region, it is important to revisit the working of SAARC and embark on an academic discourse on how to make regional cooperation more effective. The Indian Ocean today has become the gateway not only to Asia but to the rest of the world. SAARC as a functionalist organization for Peace would achieve what we need most in the region, deep peaceful cooperation .Primarily, based on the above key theoretical assumption of Functionalism; this paper aims to investigate its application to study the role of SAARC in maintaining the regional peace and security. Further this paper draws insights from its last summit; $18^{\text {th }}$ SAARC Summit to further scrutinizes the functional utility of the organization.

Key Words: Functionalism, Regional Cooperation, SAARC, Peace

\section{Background}

International Organizations and Institutions have become a way of life in South Asia since the end of World War II. The scholarship on the International Organizations is extensive, the case studies of the European 
Union and Association of South East Asian Nations (ASEAN) amongst the success stories of the numerous international organizations that exist today. The International Relations theorists developed various theories on formation of regional and international organizations. Earlier the theories on International Society and Regime theory addressed the study of international regimes to theorize international governance. Since World War II, there is a rapid growth of many organizations for economic, social, cultural partnerships around the world. Not to be left behind the South Asian countries too came up with a plan for regional cooperation through an international /regional organization.

The World Bank in 2017 reported that despite its shared history, culture, and geography, South Asia is the least economically integrated region in the world. But with greater cooperation, the region can better develop, share resources, and foster a sense of common destiny and mutual belonging among its people (World Bank, 2015). In 2012, the Indian Council of World Affairs and Association of Asia scholars organized a two-day conference that brought together scholars and academics from all the South Asian Association for Regional Cooperation (SAARC) nations. The agenda didn't focus on how to resolve political disputes or reduce political tensions but to discuss a way forward or to reclaim its space in the world, regional integration is a must, and the time has come for SAARC to help transform South Asia in the same way that the European Union has changed Europe. Indian National Security Advisor at the time, Shivshanker Menon said: "We have a moment in history which we should seize if we wish to transform South Asia," stated during the opening address to the conference in 2012(The Diplomat, 2012). There were many other scholarly gatherings in the region on how to make SAARC a more successful regional organization since that time and continues every year in the academic debate. The success 
of SAARC so far since its inception in 1985 is the record of 18 summits to its credit is not a small achievement for a region with diversity in all spheres. As argued by Ashish Singh, despite the socio- cultural similarities, relationship among SAARC nations are characterized by mutual distrust and hostilities (2017) .Therefore, this paper examines the utility of Functional perspectives to achieve peace in South Asia through SAARC while mainly adopting the qualitative research methodology, reviewing the existing scholarly literature.

\section{Genealogy of functionalist approach}

The theory of Functionalism in International Organizations dates back to early $20^{\text {th }}$ century, when Paul Samuel Reinsch, a pioneer of the study of International Relations published a textbook in 1900 articulating on global interdependence. Writing further in 1907 on International organizations Reinsch identified key features of functionalism such functions that derive from common interests and global necessities. Functions specify the powers of the organization; Functions specify the limits of their (members) proper action; functions help to distinguish organizations from their member states. Above all, member states can be wrong - they could fail to live up to their obligations but given functions or powers; - they could make use in the best possible manner and by the use the best experts of the world. Later during the World War II era David Mitrany in an article titled "Functional approach to World Organization" published in International Affairs (1948) and further outlined the theory of functionalism in his book titled A Working Peace System (1966).

It is in the early twentieth century when international relations scholars recognized the need of global interdependence. As early 1907 scholarly writings on practical responses to practical problems, new unions, 
cooperation with other nations in the matters of administering certain economic and cultural interests, organizations with administrative structures, and meeting among members were discussed. The early scholars who talked about functions of an organization, functions deriving from common interests and global necessities, functions that specify the limits of proper action, functions specifying the powers of an organization, functions that distinguishes organizations from member states. These were the concepts that Paul Samuel Reinsch and David Mitrany articulated in their academic writings. A successful functional organization that was established during a destructive world war was the first specialized agency (later) of the United Nations, International Labour Organization.

The theories on functionalism developed further as rational functionalism was developed by Robert Keohane (1984) drew from functionalist approaches that emphasized the efficiency reasons for agreements among regime participants, and that International Organizations providing a way for states to overcome problems of collective action, high transaction costs, and information deficits or asymmetries. John Mearsheimer (1994-95) provides a useful definition of institutions as "set of rules that stipulate the ways in which states should cooperate and compete with each other."

Martin and Simmons (2002) conclude that there is a broader debate between the constructivist and rationalists on theoretical orientation of International organizations. Accordingly, a distinction between those who view international institutions as rational responses to the strategic situations in which actors find themselves, versus those who insist on a subjective interpretation of social arrangements. Further, scholars from various approaches are showing willingness to drop assumption of unitary state actors and to engage systematically in the world. For the rationalists, this has 
meant looking to domestic institutional conditions that make it rational to delegate authority to international institutions. For others working from a more sociological point of view this means drawing a wide array of transnational actors that have been empowered by democratization or international institutions( Simmons and Martin , 2002 ).

\section{Functionalist Cooperation}

Functionalism today has emerged as the dominant theory of the law of the international organizations. The fundamental idea of public institutions should serve the common good. The idea of international / regional organizations not serving the common good is unthinkable. The work of Paul S. Reinsch is examined by Jan Klabber in the context of Institutional Law in an article written in 2014 (Klabbers, 2014). According Klabber who gives a brief history of the career of Reinsch states that Reinch was already a Professor of International Politics when he embarked on his writing on international organizations. First Reinsch wrote on the virtues of internationalism, as practical responses to practical problems. That the new unions would not threaten national sovereignty. Reinsch states that [countries] while fully reserving their independence actually found it desirable, and in fact necessary, regularly and permanently to co - operated with other nations in the matter of administrating certain economic and cultural interests (Ibid, p. 665).

It is interesting to analyze the writings of Reinsch at the beginning of the $20^{\text {th }}$ century before the origin of the League of Nations, as he describes the structure of an organization and functions outlining the functionalist approach. He stated that the unions have an administrative organ, and, typically, the tasks of these organs are presented as administrative nature: collecting and disseminating information, preparing future meetings. Thus 
Reinsch laid the foundation of the design, the discussion on functions and organs of organizations came next. What is interesting is that Reinsch is an early scholar who recognized the value of international organization for peace in the world. He stated "the political nature of international organizations is channeled away from their concrete effects on member states and instead linked to their contribution to world peace. Organizations are not so much a - political but are political on higher level and for a good cause: They contribute to world peace - if "world peace" an ambition shared by statesmen (Ibid, p.658). A University Professor turned diplomat he had a positivist outlook on the cooperation of international organizations.

David Mitrany (1948), discussed cooperation among technical experts in a functional area will result in the creation of an international agency that will push nations to cooperate rather than wage war. Mitrany who was employed at the British Foreign Office during the World War II, and later as a Professor at Princeton University published his work titled $A$ Working Peace System (1966) in which he advocated the significance of functional cooperation

\section{Functionalist alternatives for cooperation}

Functionalism is a theoretical approach which emerged towards the middle of the past century as an alternative to federalist designs concerning the organization of international system" ( Alexandrescu , 2007 , p.20 ). Further Functionalism looks at the human nature and development in a very positive manner in comparison to state -centric paradigm of "power politics" or realist way of account of world affairs. According to Functionalism human beings have to rationally decide about what their needs are" (Kurt, 2009, 44). 
In this point of view, it is clear that functionalism has suggested a need centric approach to the world politics instead of power centric approach. "The distinctive characteristic of functionalism is the fact that economic and social problems produce their own resolutions; the usefulness and efficiency of concrete, issue -specific (technical) cooperation and its outcomes legitimized international cooperation"( Ibid , p.45 ). Accordingly what functionalists centrally believe is issue -specific or technical cooperation that derive from non-political domains or where the politics play at threshold level and its effects would sustain international cooperation. In other words, it is a low political agenda that look for the most appropriate "spark" for a cooperative framework which can incrementally move forward. Similarly functionalism is all about how to be organized cooperatively with a functional necessity. In the other way, it is a way of gradual process that initiates a cooperative attempt upon the "most desired and essential needs" of the nations. Therefore this study argues that functionalism is a "pathway approach" to international or regional cooperation. Likewise it is a functional logic that explains how to look for a "strategic preparation" which is based on technical needs of nations that would ultimately establish a long way for cooperation among nations. This raises several questions for the discussion; does functionalism absolutely ignore the political dimension in the cooperation? If not, to which extent it appreciates the political aspect? Answering to these questions, it would be misleading to say that functionalism is an "absolute anti- political framework" for advancing cooperation among nations. Hence it would be more appropriate to understand it as a framework trough which cooperation can be successfully intensified gradually moving from low political sphere to certain degree of politics. David Mitrany, the pioneer of functionalism "identify the manner in which states could be drawn closer together in order to develop some fields 
which ignored the limitations of political geography. This approach is called functionalism because it refers to the need of confer a functional / operational character to the relations between protagonists" ( Alexandrescu , 2007, p,25).

As suggested by Mitrani, functional necessity would be the best strategy to draw the states which are inherently power laden. "The theorist of the functionalist approach to international relations spoke about the efficiency of transferring a part of a country's economic sovereignty to international executive agencies serving a clearly defined purpose"( Ibid ). In this view, functionalism has proposed an agenda through which nation-states go for cooperation with international agencies based on specified purposes at the lowest political cost.

A variation of functionalism, namely neo-functionalism, became an idea to reckon with due to the experience of the post-World War II integration of Europe. As explained by Ernst B. Haas (1958), over and above technical issues, it is political parties, interest groups, and the views of political elites that influence cooperation. A spill-over from one functional area to another is also likely but conditional on the additional factors.

Other prominent scholars who developed the theory along neofunctionalist lines are Philippe C. Schmitter, Joseph S. Nye and Robert O. Keohane. Writing on "After Hegemony: Transatlantic Economic Relations in the Next Decade" Keohane in 1983/84 raised the question of "How could it be possible for several independent, self - interested states to cooperate effectively, without a dominant power to devise a strategy and provide incentives for others to comply with its designs?" Answering his own question he refers to cooperation without hegemony. He outlines 
four conditions that must be met for cooperation to be feasible (Keohane , 2015, 86 ). These conditions make rational for functionalism as well as when Keohane refers to "Institutions are also important, since they reduce transaction costs, provide information, and may increase the probability that the same actors will continue to interact with each other in the future"( Ibid , p.87). Rational functionalism in cooperation is further strengthened when Keohane states that in the demise of hegemony increases the need for international regimes and institutions. The institutions are particularly important as they increase the chances that frequent future interactions will take place (Ibid, p.91). His work explains that functionalist approaches emphasize the efficiency reasons for agreements among regime participants. This approach provides the states to overcome problems of collective action and high transaction costs.

John J. Mearsheimer, a Professor in Political Science who does not believe that institutions are effective, writing on "The False promise of International Institutions" provides a valuable definition of international institutions as "set of rules that stipulate the ways in which states should cooperated and compete with each other" ( Marsheimer, 1994/95, p.8 ). Mearsheimer, a neo- realist does not believe that institutions are effective nor they prevent war. He states that genuine peace, or a world where states do not compete for power, is not likely, according to realism. At the same time he says that realists also recognize that states sometimes operate through institutions. However, they believe that those rules reflect state calculations of self - interest based primarily on the international distribution of power such as the North Atlantic Treaty Organization (NATO) ( Ibid , p.13 ). 
There are many scholars who have contributed to the various theoretical stands of international organizations and institutions. However this paper is limited to adopting functionalism to make SAARC a more successful organization to bring sustainable peace to South Asia. None of these objectives can be realized by South Asian countries alone. All South Asian nations require optimal way of engaging with regional cooperation. Therefore, the central concern of this study is to explore the utility of functional approach to achieve peace in South Asia. Hence the following case studies splendidly indicates the growing evidence of continuing threats to peace in South Asia, pandemics along with resurgence of ethno-nationalist conflicts in the region

\section{Intra - Inter Conflict ${ }^{3}$ case studies in South Asia}

\section{Afghanistan: a fragile political destiny}

A landlocked country in South Asia, Afghanistan was the last to join the SAARC. It gained independence from the British in 1919. The monarchy in Afghanistan was abolished and the military that took over the country declared it a republic in 1973. The Soviet Union whose support was extended to Afghanistan before the coup was more apparent since 1973. When in 1979 with the support of the Soviet troops another military coup took place it signaled the beginning of the intrastate armed conflict in Afghanistan where around one million people died in the ensuing war. The armed groups, opposing against the government, organized by exiled leaders carried out a fight against the Soviet backed government. These groups were called Mujahideen. When the Soviet Union withdrew its troops in 1988 and the diverse groups who were active in the political life of Afghanistan started

\footnotetext{
${ }^{3}$ The following is from the University of Uppsala, Department of Peace and Conflict Studies, Uppsala Conflict Data Program, see http://ucdp.uu.se/
} 
competing for power. Conflicts, mostly violent by nature took place among the shifting alliances. With growing discontent among the people of the warring warlords in the 1990's a new actor suddenly emerged in Afghanistan, The Taliban. They controlled the government from 1996 2001. They established strict Islamic State based on Pashtun approach to Sharia law.

In 2001, the United States intervened Afghanistan following the September 11 attack on US soil. Taliban were removed from government. In 2002, a democratic system was installed by the new administration as the Taliban withdrew into the mountains along the border with Pakistan. Conflict resumed with Taliban as the primary insurgent group, fighting between local leaders led to several non - state conflicts. Afghanistan has been a secondary warring party to the USA in the government conflict against $\mathrm{Al}$ - Qaida since 2002 and much of the fighting has taken place in Afghan territory up to today.

\section{Bangladesh: quest for democracy}

Bangladesh became independent in 1971 after seceding from Pakistan. The independent Bangladesh was a parliamentary democracy until 1975. From 1975 to 1990 military dictators ruled Bangladesh. There have been armed struggles by the tribal groups, an intrastate armed conflict between 1974 and 1992.

Since middle of 1990's the multiparty democracy prevailed with much rivalry between the political parties resulting in elections becoming violent events. Rioting and clashes have led to non -state conflicts in the 2000's. In 2007 a caretaker military government promised to revert to multiparty 
politics and the election that followed in 2008 Awami League had a landslide victory.

A democratic form of government has prevailed amidst much conflict and violence. There have been country wide bomb attacks by the Islamic militants in the country. Since October 2017, The Rohingya Muslims who have fled military action in Myanmanr's Rakhine state has sought refuge in the country is estimated at one million (Uppsala Conflict Data Program, n.d.)

\section{India: multiple dynamics of conflict}

India has experienced inter - state conflicts over borders with both Pakistan (Kashmir) and China. In 1948, 1965, 1971 and 1999 when the conflicts reached the intensity of war. In 1962 India - and China went to war ( Ibid ).

According the country summary published in the Uppsala Conflict Data Program, India experienced number of intra - state conflicts primarily where claims were made on ethnic or religious groups to separate or become independent states. This has been so especially in India's northeast, where rebel groups based mainly on tribal communities have fought the government in Assam, Tripura, Nagaland and Manipur. The government has also fought Sikh insurgents over Punjab/ Khalistan, and various insurgent groups over the Kashmir area, which is also claimed by Pakistan. Regarding government power the Indian government has confronted several Communist groups, such as the Maoist Communist Centre (MCC), the People's War Group (PWG) and the Communist Party of India-Maoist (CPI-M). Most of these conflicts have taken place both in the Cold War and post-Cold War eras (Ibid).

Tensions between the large number of ethnic and religious groups that populate India have also given rise to a number of non-state conflicts. 
Primarily these have centered on the Hindu-Muslim divide, but conflicts have also been recorded between tribal groups (such as Assamese against Biharis) and different factions of rebel groups (such as clashes between different organizations in Nagaland) (Ibid).

\section{Nepal: hope for peace and democracy}

Highly centralized Rana era brought down in 1951 by an alliance of the monarchy and the intellectual elite, backed by Nepal's powerful neighbor, India. In 1959, the first ever multi-party elections took place and the centerleft Nepali Congress Party (Congress) won with a landslide victory (Ibid). Few months later the monarchy took over declaring that the parliamentary democracy a failure and went on to ban political parties in the country sparking an intra - state conflict. Nepali Congress Party in 1960-1962. Congress led a guerrilla force of about 3,000 enlisted and the attacks were launched from the Indian border region as Congress had the support of India. The centrality of Indian support was also made evident in the way the conflict ended; Congress called off the armed campaign on the request of Nehru, who was facing an inter-state conflict with China and needed to garner the Nepali king's cooperation. With the end of the Congress insurgency, the royal palace was free to instate its new form of governance in 1962 called the panchayat (village councils), a party-less system modeled on some form of 'guided' democracy. The panchayat structure collapsed in 1990 after a watershed campaign launched by a broad-based democracy movement and constitutional monarchy under multi-party democracy was introduced. However, the democratic system was quickly tarnished in the general populace's eyes as the political elite in the capital squabbled for power and failed to address the structural issues and injustices in Nepal. Against this backdrop, the CPN-M (Communist Party of Nepal - Maoist) 
launched an intra-state conflict against the government in 1996. As the CPNM quickly controlled large parts of Nepal's rural areas and managed to mobilize (some by coercion) a vast number of rebel fighters, the fighting was more or less sustained for a decade. Within the context of this conflict, both the government and the CPN-M have employed one-sided violence.

In 2006, the major political parties, in cooperation with the CPN-M, organized massive countrywide demonstrations for the restoration of democracy, forcing King Gyanendra to relinquish power. On April 24, 2006, the monarch reinstated the parliament with a prime minister from the Nepali Congress Party.

\section{Narratives of Civil War of Sri Lanka}

Since independence from the British in 1948, Ceylon renamed Sri Lanka 1972 remained a democracy.There were several incidents of ethnic based conflicts and violence in the country, the first was the outbreak of violence in 1956 at the introduction of "Sinhala only" act ( Ibid ). Another intra-state conflict that took place was over government power, began in 1971 when the JanathaVimukthiPeramuna (JVP) took up arms against the government of Sri Lanka. The JVP was a communist group, which sought to topple the government in favour of a communist state. This conflict took place in stages, first in 1971 and then in 1989-1990. A sizeable youth population lost their lives as a result of this conflict.

Intra-state conflict broke out in 1983 as Tamil militant groups intensified actions against the government of Sri Lanka after several years of lowintensity conflict. Among the Tamil people of Sri Lanka, the dominant Tamil group soon became the Liberation Tigers of Tamil Eelam (LTTE), which devoured its weaker opponents within the Tamil community. Yet, the Tamils 
from the estate sector remained separated from the LTTE. Several rounds of negotiations to resolve the conflict, and several announced ceasefires, have failed to settle the conflict over the status of what many Tamils feel is their righteous 'homeland'. In May 2009, after a period of intensive fighting, the government declared that the war was over. Almost the entire political and military leadership of LTTE had been killed and the group recognised defeat after nearly 30 years of civil war and conflict. Around 70,000 to 80, 000 lives were lost in this ethnic conflict.

Since the end of war in 2009 , the civil society from that time and the government that came to power in 2015 began in earnest to promote reconciliation and sustainable peace among the diverse population in Sri Lanka. In 2011, and again in 2018 there were serious obstacles for the reconciliation measures when violence erupted between Sinhala - Muslim communities in several places in the country.

Above case studies have been presented in brief while there is much more to be said in detail. The idea is to present a summary that is relevant to the discussion. Also it is noteworthy to identify while all countries (except Bhutan) underwent periods of intra conflicts in the country, few of those have become major Inter Conflict and War in the region. This has affected the way forward and the economic and political success of SAARC.

\section{Challenges for Peace in South Asia}

There are many challenges for peaceful regional cooperation in South Asia, most of these are non - traditional security challenges while what is stated in the previous section are the traditional security threats for peace in the region. Apart from the country case studies, the traditional security threats are challenge for peace in South Asia. Among them, nuclear arsenal, absence 
of no - first use policy of nuclear arms in Pakistan, terrorism, unregulated floating armoires in the Indian Ocean and maritime piracy are some of them. The number one priority for SAARC would be to obtain no first use of nuclear policy implemented as a Regional body. At present two rivals in the region, both possess Nuclear weapons. Both countries have gone into war with each other previously.

Hence the no first use of nuclear weapons is an important pledge that needs to be in place. In India, normal nuclear doctrine from January 2003 includes a no first use pledge, albeit with caveats, and this has been emphasized by numerous Indian officials. Its diplomats have often advanced the country's commitment not to use nuclear weapons first as proof of the country being a "responsible" state and thereby a way to resist any pressures to sign any treaties that would affect its nuclear arsenal. It would seem then that the NFU is a core element of India's nuclear weapons posture ( Hagerty, 2015 ).

Among the non - traditional security challenges in South Asia, one would be the use of the Indian Ocean. Apart from the SAARC countries there are around 18 other countries in the Indian Ocean. For all of them, there are serious issues relating to environmental governance. The significant increase in garbage disposal into the sea, particularly non bio -degradable plastic items, has raised sea pollution levels in the Indian Ocean. SAARC should be able to step in here to address the issue as a functionalist organization. Next is, SAARC should in its economic integration implement policies on economic activities, SAARC countries (except 3 member states) are surrounded by the Indian Ocean. SAARC should take into consideration the increased political will to look at the Indian Ocean regions as a whole new frontier for economic dynamism. The fish stock in the Indian Ocean would be an ample supply to the region and world if proper use is made in fish 
harvesting. But no proper fishing policies are in place. Questions such as what fishing rights do outside countries enjoy, overfishing are some of the challenges to be resolved. The peaceful use of the Indian Ocean will ensure an abundance of food supply for many countries in South Asia. SAARC has had only very limited success in deepening economic cooperation due to tensions between major economics in the region.

On the Indian Ocean, it has a wealth of mineral and energy resources, hitherto unexplored. SAARC could be in the forefront with other Indian Ocean regional groupings such as Indian Ocean Rim Association (IORA) and The Bay of Bengal Initiative for Multi-Sectorial Technical and Economic Cooperation (BIMSTEC) in implementing policies of economic cooperation.

Water security is another challenge for peace in South Asia. Ensuring state cooperation for water security is another priority for SAARC. In the context of environmental governance, drinking water is an issue for many of the South Asian countries except Sri Lanka and Bhutan.

\section{$18^{\text {th }}$ SAARC Summit: Peace through functional collaboration}

Ensuring regional peace requires greater cooperation among South Asian nations while addressing political vulnerabilities deriving from a multiplicity of factors. What is evidently present in contemporary South Asia is these vulnerabilities are mainly shaped and motivated by political factors such as mutual mistrust, asymmetries embedded in regional politics, bilateral disputes among nations and domestic political conditions. Hence both domestic and regional politics can determine peace in South Asia. As discussed in this paper, this political complexity of achieving peace can be successfully addressed with the functionalist alternatives. Therefore, this 
study explores the functional agenda embedded in $18^{\text {th }}$ SAARC Summit and its utility to sustain peace in the region.

Looking at the declaration of the 18th SAARC summit from the functionalist lens, it is clear that the declaration has given substantial attention for a functional agenda trough which region can move forward cooperatively. As viewed by the leaders, building connectivity through roads, railways and enhancing the cooperation in the field of energy is crucial to upgrade the regional cooperation in South Asia (SAARC Summit Declaration, 2015). Apart from that, SAARC leaders have agreed to "identify regional and subregional projects in the area of power generation, transmission and power trade, including hydropower, natural gas, solar, wind and bio- fuel, and implement them with high priority with a view to meeting the increasing demand for power in the region( Ibid ). In addition to this prominent functional scheme, the declaration has looked for a cooperative mechanism in the areas of agriculture, poverty alleviation, environment, blue economy, health, education, youth women and children. Moving beyond, effective collaboration in the aspects of science and technology, tourism, culture, media, combating terrorism and promoting good governance are some of other expectations of the declaration (Ibid). Given the large number of policy interests, this study suggests three main categories that classify the agreed cooperative endeavors in the declaration.

- Absolute functional areas - energy sector cooperation, connectivity agreements, technology

- Socio-economic and welfare areas -agriculture, poverty alleviation, environment, blue economy, health, education, tourism , culture , media 
- Political and security areas - combating terrorism and promoting good governance

Hence this paper argues that absolute functional areas are mostly compatible with the functionalist agenda as political sensitiveness is relatively less in these areas. Somehow Socio-economic and welfare areas are still attached to country's individual political agendas. Henceforth the political sensitiveness is relatively high and SAARC member countries may have multiple frameworks to achieve such goals appealing to their own domestic political atmospheres. The third category; political and security areas seems to be more political sensitive spaces to which member countries are very conscious in terms of their national sovereignty. Therefore the degree of cooperation in this sector will be hardly determined by the political will of the member countries. What further is, it is apparent that proposed cooperative agenda by the $18^{\text {th }}$ SAARC summit can be hierarchically arranged according to the degree of "political sensitiveness" and the "common functional necessity" in different sectors.

Particularly, "one of the key inputs needed to sustain and accelerate economic growth in the region is increasing access to energy, as there is sarong direct relationship between economic growth and energy demand. Upward social mobility associated with faster economic growth further accentuates the demand energy" (Asian Development Bank, 2011). Further Asian Development Bank reveals that cross-border electricity transmissions, regional trade in energy sources such as electricity, petroleum and natural gases are the best incentives that can accelerate the regional cooperation in the region (Ibid ). Indeed South Asia is a vast powerhouse in terms of its market potential (one-third of humanity resides in this area) and in terms of richly endowed natural resources (e.g., the water of Nepal, natural gas of Bangladesh, coal of India) and qualified human resources" ( Bhatia, 2004, 
p.7 ). For an instance Bangladesh is the largest natural gas producer in Asia 2012 and it has increased natural gas production by annual average of 7 percent over the past decade (US Energy Information Administration data, 2015). Moreover "despite having potential the highest commercially feasible

hydropower potential, Nepal has harnessed about 1 percent, far below the level of every other South Asian Country"( Ibid , p.8 ). Concurrently India had approximately 47 percent of proved natural gas reserves at the beginning

\begin{tabular}{|l|l|l|l|l|}
\hline & $\begin{array}{l}\text { Absolute } \\
\text { Functional Areas }\end{array}$ & $\begin{array}{l}\text { Socio-economic } \\
\text { and welfare areas }\end{array}$ & $\begin{array}{l}\text { Political and } \\
\text { Security areas }\end{array}$ \\
\hline $\begin{array}{l}\text { Political } \\
\text { Sensitiveness }\end{array}$ & $\downarrow$ & Relatively high $\uparrow$ & $\uparrow$ & High \\
\hline $\begin{array}{l}\text { Common } \\
\text { Functional } \\
\text { Necessity }\end{array}$ & Relatively less & $\uparrow$ & Optional & Low \\
\hline
\end{tabular}

of 2014 counting 34 percent for on shore reserves and 36 percent for off shore reserves( US Energy Information Administration data, 2015).

Figure 1: Grid Analysis on Functionalist Scrutiny for $18^{\text {th }}$ SAARC Summit Declaration

Source: Authors

This statistical analysis proves how South Asian counties are potential for energy sector cooperation with their available and unexplored resources. Hence below grid analysis further demonstrates the relevance of suggested functional agenda adopted by the $18^{\text {th }}$ SAARC summit in the light of their political sensitiveness and common functional necessity. 
According to the above grid analysis, what is clear is that absolute functional areas associated with energy cooperation, connectivity agreements and technology are more compatible with the functionalist prospect of cooperation as their political sensitive is relatively less and functional necessity is considerably high. Therefore it can be argued that the $18^{\text {th }}$ SAARC declaration is partially fitting to the functionalist framework in terms of absolute functional areas through which the SAARC mainly can accelerate its regional cooperation with higher expectations. Secondly it can look for socio-economic and welfare areas and perhaps political-security areas at the last.

Focusing on this partial compatibility of the 18th SAARC declaration with functionalist agenda, it is also noteworthy to have a brief critical account for what is absent in the 18th SAARC summit from David Mitrani's points of view. The following tabulation clearly indicates where the $18^{\text {th }}$ SAARC summit can be positioned in the light of David Mitrany's functional agenda.

\section{Figure 2: David Mitrany's Perspectives and the $18^{\text {th }}$ SAARC Summit}

\section{Declaration}

\begin{tabular}{|l|l|l|}
\hline $\begin{array}{c}\text { Mitrany's functional } \\
\text { suggestions }\end{array}$ & \multicolumn{1}{|c|}{$\mathbf{1 8}^{\text {th }}$ SAARC Summit } & \multicolumn{1}{|c|}{ Remarks } \\
\hline $\begin{array}{l}\text { Identification of } \\
\text { functional alternatives } \\
\text { for cooperation }\end{array}$ & $\begin{array}{l}\text { Reasonably present in the } \\
\text { declaration ranging from } \\
\text { energy to environmental } \\
\text { aspects. }\end{array}$ & $\begin{array}{l}\text { More ambitious and wide array } \\
\text { of functional alternatives are } \\
\text { identified hence hierarchical } \\
\text { consideration or prioritization } \\
\text { is needed }\end{array}$ \\
\hline $\begin{array}{l}\text { Highest possible degree } \\
\text { of active forces and } \\
\text { opportunities for } \\
\text { cooperation }\end{array}$ & $\begin{array}{l}\text { Can be found under a } \\
\text { categorical analysis e.g. } \\
\text { Absolute functional areas }\end{array}$ & $\begin{array}{l}\text { Such active forces and } \\
\text { opportunities are merely } \\
\text { presented instead of } \\
\text { categorizing them based on the } \\
\text { degree of potentials for } \\
\text { cooperation }\end{array}$ \\
\hline
\end{tabular}




\begin{tabular}{|l|l|l|}
\hline $\begin{array}{l}\text { Specific selection and } \\
\text { separate organization } \\
\text { of interests }\end{array}$ & $\begin{array}{l}\text { Several functional } \\
\text { suggestions and interests } \\
\text { can be identified instead of } \\
\text { well-focused or specified } \\
\text { one }\end{array}$ & $\begin{array}{l}\text { Specification and organization } \\
\text { of such interests is needed }\end{array}$ \\
\hline $\begin{array}{l}\text { Incremental progress of } \\
\text { functional cooperation }\end{array}$ & $\begin{array}{l}\text { A framework that ensure } \\
\text { such incremental progress } \\
\text { in cooperation is absent }\end{array}$ & $\begin{array}{l}\text { How proposed functional } \\
\text { activities can be gradually } \\
\text { enhanced through a proper } \\
\text { mechanism. }\end{array}$ \\
\hline $\begin{array}{l}\text { Ramification process to } \\
\text { attribute the autonomy } \\
\text { for functional agencies }\end{array}$ & $\begin{array}{l}\text { No such clearly defined } \\
\text { ramification process in the } \\
\text { declaration }\end{array}$ & $\begin{array}{l}\text { It requires specified functional } \\
\text { agencies with certain autonomy }\end{array}$ \\
\hline
\end{tabular}

Adopted from (Mitrany , 1966)

As analyzed by the above table, it is clear that $18^{\text {th }}$ SAARC summit is partially compatible with the functionalism as it demonstrates some deviations from functionalist agenda in terms of specification of functional interests and a framework through which cooperation can be incrementally achieved. In other words the $18^{\text {th }}$ SAARC summit has provided more ambitious and wider functional alternatives being further deviated from what really functionalists have emphasized. Therefore what absence in the $18^{\text {th }}$ SAARC summit declaration is clear identification of functional areas along with specified functional interests through which South Asian nations can accelerate regional cooperation. Further, the $18^{\text {th }}$ SAARC summit declaration has not properly answered the questions of how to initiate the functional cooperation and how to progress the cooperation systematically through a gradual mechanism. Similarly, the $18^{\text {th }}$ SAARC declaration has paid little attention to an appropriate "functional logic" on which South Asian regional cooperation can sustain.

\section{Conclusion}


From a socio -economic perspective, South Asia today, is one of the most dynamic regions in the world, with a population of 1.67 billion people and economic growth of 7.1 percent over the last decade. The World Bank stated in 2012, that South Asia will play an important role in the global development story as it takes its place in the Asian Century. It has the world's largest working age population, a quarter of the world's middle-class consumers, the largest number of poor and undernourished in the world, and several fragile states of global geopolitical importance. With inclusive growth, South Asia has the potential to change global poverty through functional cooperation while waving a path for sustainable peace.

In the context of promoting regional peace, South Asia is a region where several major religions that promote peace were born and spread to the world. A region with a rich heritage and culture, South Asia has enormous potentials. The powerful non state actor who preached non - violence and had a mass following from around the world is a South Asian. It is a region that was successful introducing the Indian Ocean Peace Zone proposal in 1975, A UN resolution in the height of Cold War. In contributing to World Peace today, South Asia leads the way in United Nations Peacekeeping. World's largest troop contribution to UN Peacekeeping comes from South Asia with India, Bangladesh, Pakistan and Nepal among the top 5 troop contributors.

Yet the historical political tensions resulting in mistrusts cross border conflicts and traditional and non - traditional security threats have marred successful regional integration and SAARC a somewhat failed body. Therefore, the study has suggested an acceptable hierarchy of functional areas in which contemporary SAARC can achieve effective cooperation in the functional terms with the minimum interruption of political sensitiveness. 
As argued by the paper the 18th SAARC declaration should be located in a domain where the functional utility is higher for member states with positive storylines. Then the cooperative agenda proposed by the 18th SAARC summit will be more pragmatic and effective. So that, SAARC can sustain Peace in South Asia as a functionalist organization while prioritizing functional necessities derive from common regional interests. Further, these functional necessities should be specifically recognized and appropriately integrated in a low political domain.

Hence, this paper explores several prospects for SAARC to be a more effective regional organization to achieve regional peace .Firstly; South Asia has to collectively address the factors influencing both intraregional relations and its relations with the outside world. Thus, SAARC cannot afford to ignore the both traditional and non-traditional security challenges arising from the above context. Secondly, SAARC has to identify a common functional framework through which its members can gain variety of gains. More specifically, economic gains can be the priority of such framework with the emphasis of necessary social and political cooperation. As the third point, SAARC needs to incrementally develop a cooperative plan for regional peace based on common functional necessities. Particularly, SAARC Summits can serve as effective forums where the SAARC leaders can afford for consensus building and enhancing mutual trust for ensuring peace in the region. Finally, SAARC members should adopt an approach to make sure that both domestic and regional issues are not a deterrent to achieve regional peace and cooperation. To elaborate, SAARC members should strategically ignore their bilateral disputes which are largely shaped by socio- historic and geographical factors and promote functional collaboration among the nations. As history evidently shows South Asia has more often been a source of conflict which has hampered the regional 
cooperation in many ways. Therefore, cultural and communal similarities of the region along with functional necessities can serve as an appropriate basis for establishing peace in the region.

\section{List of references}

Afroze, S. (2002) Regional Cooperation In South Asia : New Dimensions and Perspectives. Dhaka: Bangladesh Institute of International and Strategic Studies .

Agarwal, P. (2006) South Asia : Peace Security and Development. New Delhi: Kilaso Books.

Alexandrescu, M. (2007) David Mithrani from Federalism to Functionalism. Transylvanian Review 16,1.

Bank, W. (2015, September 06) Regional Integration; the answer to South Asia's Development. Retrieved April 23, 2018, from http://www.worldbank.org/en/news/video/ 2015/11/06/regional-integration-the-answer-to-south-asias-development

Bhatnagar, Z. S. ( 2008) SAARC and Interstate Conflicts in South Asia: Prospects and Challenges for Regionalism. Pakistan Horizon , 69-87.

Bhattacharya, B. N. (2014) Prospects and Challenges of Intergrating South and South East Asia. International Journal of Development and Conflict ,4 , 40-66.

Dash, K. C. (2008) Regionalism in South Asia Negotiating cooperation, institutional structures. New York: Routledge .

Gajanayake, N. (2014, December 16th) The 18th SAARC Summit: Platform of hope. LKIIRSS , pp. 1-4.

Gippner, O. (2010) Energy Cooperation in South Asia:Prospects and Challenges. Kathmandu: South Asia Watch on Trade, Economics and Environment.

Handbook of International Relations. (2002) Thousand Oaks: Sage Publications .

Hegerty, D. T. India's Evolving Nuclear Posture. Retrieved May 23, 2018, from The NonPoliferation Review: https://www.tandfonline.com/doi/full/10.1080/10736700.2014.10729 90? scroll=top\&needAccess $=$ true

Keohane, R. O. (2015) "After Hegemony: Transatlantic Economic Relations in the Next Decade". The International Spectator.

Klabbers, J. (2014) The Emergence of Functionalism in International Institutional Law: Colonial Inspirations. Thee European Journal of International Law EJIL , 645 - 675.

Kurt, Ü. (2009) Europe of Monnet, Schumann and Mitrany: A Historical Glance to the EU from the Functionalist Perspective. European Journal of Economic and Political Studies 2,2. 
Mearsheime, J. J. (1994/95) The False Promise of International Institution. International Security Winter.

Mitrani, D. (1966) A Working Peace System. Quadrangle Books.

Nikki Slocum, Luk Van Lanenhove. (2003) The meaning of Regional Integration : Introducing Positioning Theory in Regional Integration Studies. UNU-CRIS e-Working Papers, 5 .

Rajiv Bhatia, Swaran Singh, Reena Marwah. (2014) Transforming South Asia Imperatives for Action . New Delhi: Indian Council of World Affiars .

Saifuddin Soz, R.N.Sivastava. (2010) SAARC Emerging Challenges. New Delhi: Foundation for Peace and Sustainable Development.

Shaheen Afronze (ed., ) (2002) Regional Cooperation in South Asia. Dhaka: Bangladesh Institute of International and Strategic Studies .

Singh, A. (2017) Functional Cooperation in SAARC and Other Regional Posibilities . Indian Jurnal of Political Science and Sociology, 41-44.

Sridharan, E. (2011) International Relations Theory and South Asia . New Delhi: OXford University Press.

Sultan Hafeez Rahman, Sridhar Khatri, Hans-Peter Brunner. (2012) Regional Integration and Economic Development in South Asia. 2012: Asian Development Bank .

Sultan Hafeez Rahman,Priyantha D. C. Wijayatunga ,Herath Gunatilake, P. N. Fernando. (2012) Energy Trade in South Asia Oppertunities and Challenges. Metro Manila: Asian Development Bank.

The Deplomat Retrieved April 22, 2018, from https://thediplomat.com /2012/03/can-saarcbe-south-asias-eu/

Uppsala, U. o. Uppsala Conflict Data Program. Retrieved May 22, 2018, from Department of Peace and Conflict Studies: http://ucdp.uu.se/

Vinodan, C. (2014) South Asia in the Globalized World. New Delhi: New Century Publications. 